\title{
The Pandemic Health Crisis and Its Implications for Food and Nutritional Security in Latin America
}

\author{
Rubia Carla Formighieri Giordani Islândia Bezerra da Costa \\ Nutrition Department, Federal University of Paraná, Curitiba, Brazil
}

\section{Keywords}

Pandemic · COVID-19 · Food insecurity · Latin America

\begin{abstract}
The inequalities in health are directly linked to food and to the nutritional profile; hunger and malnutrition, as well as overweight and obesity, increase in proportion to poverty. In the current COVID-19 pandemic scenario, social isolation measures implemented in several countries to prevent the collapse of health systems impose new rhythms on people's lives and their daily routines, implying a reorganization of their vital structure and the necessary activities for its maintenance and reproduction. The restriction of circulation with the requirement to prepare food inside the home imposes food planning with options with some degree of industrial processing. In the diet of isolation, among the likely changes in food consumption models, there will certainly be an increase in ultraprocessed foods, mainly because containment measures have altered the dynamics of circulation and local trade of fresh products.
\end{abstract}

(c) 2021 The Author(s). Published by S. Karger AG, Basel on behalf of NOVA National School of Public Health

karger@karger.com www.karger.com/pjp

Karger $\stackrel{\text { ' }}{5}$

BOPEN ACCESS (c) 2021 The Author(s). Published by S. Karger AG, Basel on behalf of NOVA National School of Public Health

This article is licensed under the Creative Commons AttributionNonCommercial-NoDerivatives 4.0 International License (CC BYNC-ND) (http://www.karger.com/Services/OpenAccessLicense) Usage and distribution for commercial purposes as well as any distribution of modified material requires written permission.

\author{
A crise sanitária pandêmica e suas implicações na \\ insegurança alimentar e nutricional da América \\ Latina
}

\section{Palavras Chave}

Pandemia · COVID-19 · Insegurança alimentar · América Latina

\section{Resumo}

As iniquidades em saúde estão diretamente conectadas com a alimentação e, por sua vez, com o perfil nutricional: a fome e a desnutrição, assim como o sobrepeso e a obesidade aumentam proporcionalmente à pobreza. No atual cenário de pandemia da Covid-19 as medidas de isolamento social implementadas em vários países para evitar o colapso dos sistemas de saúde impõem novos ritmos às vidas cotidianas das pessoas e implicam em uma reorganização da estrutura vital das atividades necessárias a sua manutenção e reprodução. A restrição de circulação com a exigência de preparar a comida dentro do domicílio impõe um planejamento alimentar com opções dos produtos com algum grau de processamento industrial. Na die-
Rubia Carla Formighieri Giordani

Nutrition Department, Federal University of Paraná

Avenida Prefeito Lothário Meissner, 632

Curitiba, Paraná 80210-170 (Brasil)

rubiagiordani@gmail.com 
ta do isolamento, dentre as prováveis mudanças nos modelos de consumo de alimentos, certamente haverá o incremento dos ultraprocessados, principalmente porque as medidas de contenção alteraram as dinâmicas de circulação e comércio local de produtos frescos.

( 2021 The Author(s). Published by S. Karger AG, Basel on behalf of NOVA National School of Public Health

\section{Introduction}

A recent United Nations report estimates that food and nutritional insecurity is expected to reach 265 million people worldwide due to the SARS coV-2 pandemic [1].

Even before the pandemic, the agricultural model and the global food trade presented serious distortions of availability and access to food in certain continents. There is more food than would be necessary to feed all of humanity, yet about 800 million people are hungry in the world. Moreover, 2 billion people are overweight or obese due to contradictions of the hegemonic agrifood system, which historically has consolidated itself as it has also gradually increased the supply of food products with a low nutritional value. In other words, contrary to what the Organization for Economic Cooperation and Development (OECD) stated in a recent analysis [2], the food production model implemented on a global scale, which we identify here as the Green Revolution, was not able to mitigate inequalities in access to healthy food and, contrary to what the OECD [2] suggests, this productive model needs to be revised in its structures if we want to think about a resilient, sustainable, and productive global food system.

Food security, according to the Food and Agriculture Organization (FAO) and the World Health Organization (WHO), refers to ensuring continued access for all people to sufficient quantities of safe food that secure an adequate diet to achieve and maintain the health and nutritional well-being of all people [3].

This concept has been expanded, especially in debates in countries with peripheral economies. In many of these contexts, public policy agendas have been incorporating other dimensions besides production, availability, and access to food in the last few decades and have sought to critically reposition the role of emerging economies in the global agrifood system. The impositions of the hegemonic system on ways of living and eating started to be questioned. And the discussion of food security began to reverberate equally in criticisms about cultural ordering and rationalities and their effects on local food cultures.

The Pandemic Health Crisis and FNS in Latin America
For the proposed debate, we start from an expanded conception of food and nutritional insecurity. Health inequities and contradictions in the nutritional and epidemiological profile of populations in countries with peripheral economies are included as part of the gears that move the hegemonic agrifood system and are necessary for its maintenance. We seek to situate the crisis in terms of historical continuities on the continent and we venture its developments beyond the increase in poverty and hunger. In this article, we intended to contribute with a critical reflection in the field of public health that takes the crisis as a device that may accentuate a trend of transformations already underway. i.e., of the food models becoming more homogeneous and structured with the reinforcement of the food industry and with the increase in ultraprocessed products in the daily diet of Latin American populations.

\section{Inequities in Health and Fragile Systems: What Is the Impact of the Pandemic in Latin America and the Caribbean?}

The pandemic will disproportionately and unequally affect different societies around the globe. From the point of view of food insecurity, the health crisis exacerbates and accelerates the worsening risk of hunger in Central America, parts of the Andes, and the northeastern region of Brazil. These places are more susceptible to decreased food production due to climate change [4]. An FAO report projected displacements (in altitude and latitude) of regions of prime crops for the region's food security, especially those crops that require greater amounts of water [5]. Latin American countries that have their economies based on agricultural production - which accounts for $5 \%$ of the regional gross domestic product, $23 \%$ of exports, and about $16 \%$ of jobs - will suffer considerably from the impact of global warming on their food systems. In addition, they will also be the most impacted by the pandemic health crisis $[5,6]$. It is estimated that the economies most affected by climate change are the ones that already exhibit greater weaknesses in their food systems, such as those of Bolivia, Ecuador, El Salvador, Honduras, Nicaragua, and Paraguay. It is important to mention that these countries also have weak health systems.

The developing and poorest countries present a low response capacity imposed by historically determined structural weaknesses (social and economic). During this time of confronting the SARS-CoV-2 pandemic, these weaknesses will strongly impact their health systems, 
which, surely, will suffer the biggest impacts. This can be seen as a result of the alignment between the neoliberal measures in place and the precepts governing world macroeconomics [7-9]. The social effects will be even more aggressive in these countries because their economies are peripheral and dependent, which fatally puts their health systems at a disadvantage in the war against the pandemic.

Many countries in the region have made important changes to their social protection systems by expanding investments that have enabled a greater coverage and impact of their actions. However, the prepandemic scenario was already discouraging, indicating economic recession and reduced growth [10]. Now, these projections are aggravated by the pandemic and will further hinder equity and social justice in these countries [11].

The health care crisis and the social costs of the pandemic will be particularly severe for fragile economies. At the beginning of the pandemic, the Economic Commission for Latin America and the Caribbean (ECLAC) predicted a deep economic recession with a fall in gross domestic product of $1.8-4 \%$ and a significant increase in poverty in the Latin America and the Caribbean (LAC) region, which could reach around 209 million people [12]. These rates reverberate directly in the level of food insecurity and in the demands of health services.

The process of economic slowdown identified since 2018 reflects on the structure and quality of jobs in LAC and negatively impacts health and food security. The International Labour Organization (ILO) estimates that more than half of the economically active population in these regions is in labor informality and in-work poverty. The reality is not homogeneous in the region and countries with a higher per capita income, such as Argentina, Uruguay, Chile, and Brazil, have lower rates in comparison to countries in Central America, such as Honduras, where informality can reach $70 \%$ of workers [13]. According to this ILO document - before COVID-19 - there were an estimated 27 million unemployed people in 2019 . This projection should still be revised with more pessimistic numbers for a postpandemic scenario. In general, getting sick means impoverishment, and impoverishment has a direct impact on people's health and eating conditions [14].

The plurality of health systems in LAC reflects the historical particularities of their origins, development, and impact caused by the neoliberal measures of the 1980s and 1990s, when there were promarket actions and the retreat of the state $[12,15,16]$. Brazil, for example, is the only capitalist country in the region that has a universal health system that is free for the entire population. The Brazilian Unified Health System (SUS; strongly inspired by the Welfare States of Great Britain and Italy) was created and implemented in 1988 as a result of a major health reform in the country and currently serves 208.5 million Brazilians. However, the SUS has suffered from chronic underfunding over the years, including budget restrictions that historically prevented advances in health programming and caused noncompliance with its principles of universality, integrality, and equity. At this point, the Unified Health System is a strong candidate for collapse $[11,17,18]$.

Colombia, Mexico, Costa Rica, and Uruguay have also implemented systems that incorporate universal health coverage guidelines in agreement with international organizations such as the World Health Organization (WHO) and the World Bank (WB) [19-23]. However, it is worth mentioning that, despite the expansion, around 28 million people in Mexico remain without coverage and that there are critical funding limitations $[24,25]$. In general, changes are slow and structural transformations are difficult to achieve. They depend on sociopolitical structures and the cycles of capitalism in the region, which, in turn, generate instabilities and uncertainties.

Thus, in addition to the heterogeneity of health systems, the extreme inequalities and social stratification in the region will impose major challenges to control the spread of SARS-CoV-2. As Abel and Frohlich [26] analyzed, "the unequal distribution of material and non-material resources leads to the reproduction of unequal life chances and limitations of choice." Therefore, the following questions are posed: how can the virus be contained in places unfit for human life? How can the spread of a disease be prevented in places without basic sanitation? Can one expect reasonable rates of physical distancing in communities where families share a single room?

A fundamental issue of the health crisis and of the false dichotomy between measures to contain the spread of the virus and the reduction or interruption of economic activities concerns the fight against hunger and food and nutritional insecurity in LAC.

The morbidity and mortality profile of Latin American populations mirrors the social and economic determinations about human life. Economic vulnerability, weak social policies, poor housing and sanitation, difficult access to health services, and fragility of the educational system are some of the structuring devices for the reproduction of health inequalities and inequities in the region [14].

All of these inequalities in health are directly linked to food and to the nutritional profile; hunger and malnutri- 
tion, as well as overweight and obesity, increase in proportion to poverty. In the Latin American context of social and political determination of food and nutritional insecurity, the following points are highlighted:

Low monetary resources that restrict healthy choices. The expansion of the food industry and the production of ultraprocessed products (with high amounts of sugar, fats, and sodium and a low fiber content), which, in turn, have more accessible prices and are distributed in increasingly capillary circulation networks, tensions the food selection of the eaters, exposing them to likely deleterious impacts on their health.

These factors are combined with a lack of regulation and abusive advertising, which also negatively interferes with the food choices of children, adolescents, young people, and adults.

The weakness of public policies that value food and nutritional security (FNS).

To continuously ensure nutritionally adequate and culturally referenced diets, policies for building food and nutritional sovereignty and security must be intersectoral. Therefore, they must also be committed to promoting socially and environmentally sustainable development in a fair and ethical manner, aiming at the well-being of future generations. Brazil already has a political and legal framework for food security as a result of a broad participatory process of organized civil society. These questions thus already made up the list of conceptual guidelines for public policies of the 2000s through the drafting of an organic law and the creation of a food security system [27]. The debate gained visibility and the political strength of a global agenda with the United Nations Sustainable Development Goals in 2015, with emphasis on goal 2 of the 2030 Agenda, i.e., "End hunger, achieve food security and improved nutrition and promote sustainable agriculture" [28].

\section{The Transformations in Commensality during the Covid-19 Pandemic}

Increasingly, people all around the world eat outside their homes. Accelerated urbanization with an increasing contingent of people living and working in cities and peripheralization of workers imposed by the distance between home and workplace are factors that have influenced these transformations in the way people eat [29].

In the current Covid-19 pandemic scenario, social isolation measures implemented in several countries to prevent the collapse of health systems impose new rhythms on people's lives and their daily routines, implying a reorganization of their vital structure and the necessary activities for its maintenance and reproduction. This situation occurs in rural and urban territories and, in spite of their differences, requires reflection regarding the food dimension.

The food supply of billions of people around the world is currently changing, either due to breaks in the outlets and disruptions in the access and consumption of short circuit food supplies (such as the closing of street markets, which are important points of access to fresh and in natura foods) or due to disruptions in the food processing stages, since they require various ingredients that, in general, are acquired outside of the production unit (e.g., sugar, vegetable oils, and spices).

The Map of Organic Fairs produced by the Brazilian Institute for Consumer Protection mapped 5,083 street markets in Brazil [30]. It is assumed that, during this time of health crisis caused by SARS-CoV-2, this number may have changed depending on fluctuations in local policy definitions.

The measures imposed affect the ways of eating not only in a global, but also in a particular way. In the pandemic economic context, such measures tend to significantly reduce commerce activities and, therefore, the consumption of more nutritionally elaborate meals such as the Brazilian "PF" (or prato-feito in Portuguese, equivalent to the "set meal" in English) model. They also reduce the consumption of snacks, which significantly moved the informal economy in LAC $[31,32]$. On the other hand, it reverberates negatively in food services of the tertiary sector; full-service commercial restaurants, self-service, fast food chains, and neighborhood diners are either closed due to the strong impact of the crisis or remain in operation with delivery systems and/or restricted service capacity $[33,34]$.

Central social policies for workers' FNS were also impacted by the health crisis. The institutional meals served in restaurants installed in the workplace represent an important mechanism to provide nutritionally balanced food. In Brazil, the Worker Food Program (or Programa de Alimentação do Trabalhador/PAT in Portuguese) is mentioned, where the employer is stimulated by granting tax incentives to afford food to the workers. Currently, the PAT serves 21,521,794 workers in Brazil. Thus, these people have been suffering the impacts of the crisis, either due to the temporary and indeterminate suspension of their activities in the workplace or due to the closure of jobs. Still in the field of social policies in Brazil, decentralized FNS facilities, such as popular restaurants, which aim 
to ensure prepared and balanced meals at more affordable prices for different segments of the population in a situation of social vulnerability, changed their operating dynamics due to the pandemic [35]. These actions, that to some extent prioritize FNS, have been strongly impacted by the pandemic, exposing the most impoverished social segments to a situation of greater food and nutritional vulnerability.

In many urban centers, eating out has not only become a necessity but also represents, in the context of modern life, the manifest essence of the logic that moves the world: the acceleration of time. The modern eater "does not spend" time making his or her own food and the food industry - in line with this new global order - offers a product/service adjusted to the "needs" of modern life [36,37].

In the 1990s, the World Health Organization [38] started to record information about the street food trade, ready-to-eat food, and food prepared and sold on public roads. In that document, it was already made explicit that this would become, in a short period of time, an important segment of the food sector, especially in developing countries, becoming a relevant economic activity due to the reduction of formal jobs, rising unemployment, and falling purchasing power.

More recent data from the Pan American Health Organization [39] and other studies [40,41] indicate that the sale of ultraprocessed products grows with urbanization. This rise occurred strongly between 2000 and 2013 in low-income countries and correlates directly with weight gain and obesity $[42,43]$.

In 2001 the FAO of the United Nations mentions that the purchase of ready-to-eat food from street vendors and market sellers was consolidated into a relevant nutritional strategy in the large urban centers of LAC. Besides, it is estimated that about $20-30 \%$ of urban household food expenses in these countries are used to buy street food [44]. In Brazil, the 2017/2018 Family Budget Survey showed that, in the urban environment, expenses with street food account for $33.9 \%$ of the total food expenses [45].

To a certain extent, street food figures in the democratization of the social space of food. Heck et al. [29], when analyzing the influential study of Gilberto Freyre [46] on Brazil, affirms that food can be considered "a basic element of the race mixture that forged the Brazilian nation. Although scholars critiqued the notion of Brazilian 'racial democracy' globally, the culinary 'melting pot' was a fundamental trope of social integration in pluralistic societies." Street food, sold in stalls and trays, historically dating back to countries like Brazil at the time of slavery, encompasses culturally referenced strategies and practices [37]. Tinker $[47,48]$ even considered that street food in developing countries represents the cosmopolitan ways of eating through fast food chains in the Northern Hemisphere.

In rural areas, the pandemic situation also generates uncertainties and conditions of food and nutritional insecurity. Family-based agriculture has its productive dynamics focused on its social reproduction, but it is also connected with urban centers [49]. This agriculture supplies cities with fresh food (vegetables, leaves, fruits, roots, stems, tubers, and nuts) and even minimally processed (peeled and/or chopped) and processed (fruit jellies, cheeses, and preserves, among others) foods through its production flow logistics (distribution, storage, and marketing), which has been directly impacted by the SARS CoV-2 health crisis.

Besides the condition of farming families that, in general, produce what they eat, many of them guide their production to some degree of trade as well, as follows:

Institutional markets such as the school feeding system. In Brazil, since 2009, it is recommended that at least $30 \%$ of the resources earmarked for the purchase of food should be destined to local family farming;

Short circuits of trade such as street markets, consumer groups, small markets, restaurants, diners, and the like (which had their service suspended or closed); and

The decrease in the presence of an intermediary, who, due to the retraction of consumption, is acquiring fresh food less frequently.

In addition, there are those farming families that, to some extent, have a relative (high, medium, or low) degree of specialization in production. For instance, they are dedicated to the production of only one or a small amount of specific items, eliminating the component of diversity in production (and, therefore, of consumption).

In general, this dimension of food diversity involves marketing of the item (or items) it produces. This results in the need to buy other foods and/or products from markets. However, during the pandemic, there are limitations not only to trade but also to moving around in their own territories due to difficulties related to transport logistics, for example. Still in this rural setting, a mention is made of the need to reflect about the condition of food and nutritional insecurity of families that have always been on the margins regarding access to basic goods and services - among these, food - which, during the pandemic, will certainly be in an even greater condition of exposure to hunger. 


\section{The Global Food System and Food and Nutritional Insecurity in LAC}

Although Latin American countries have advanced in the control of malnutrition and nutritional deficiencies in the last 2 decades, the obesity epidemic is growing markedly in all income strata, regardless of society's ethnic and racial compositions, exceeding geographical limits and the different lifestyles in urban and rural areas $[3,50,51]$.

The nutritional epidemiology indicates a paradox in the nutritional profile of LAC with relevant food and nutritional insecurity [3]. The increase in chronic noncommunicable diseases in particular, associated with the difficulty of access to a balanced diet, outweighs nutritional deficiencies related to diseases such as malnutrition, anemias, and hypovitaminosis.

In general, historical changes in food on the continent followed the expansion of the world system towards the west, including a civilizing process of eating habits [52, 53]. Especially with industrialization of the agrifood sector, there was a progressive process of consolidation of complex food production and marketing chains. The industrialization of food, consistent with the new economic and social order, expanded the access to items often produced on a large scale and at a low cost. Consequently, it leads and coerces modern eaters to adopt more or less defined models of selection and consumption of products from the food industry.

Current dietary regimes involve sets of economic, political, and institutional relationships in which diets (food consumption) and agricultural production are interconnected in such a way that they engender processes of expansion and accumulation, forming a robust global agrifood system $[54,55]$. In the case of Latin American food systems, there is a latent contradiction. In particular, there is the Brazilian model, which presents a disconnect between the agro-industrial sector (more aligned with the demands of global markets) and the supply of the domestic market and domestic food security, causing enormous difficulty related to the economic accessibility of food by the population [56].

These urban models of commensality are often described as eating practices based predominantly on food with a high energy content and poor nutritional value. They were widely and quickly adopted in Latin America, especially during the postwar period, indicating an interterritorial homogenization $[57,58]$.

For the Pan American Health Organization [39], in general, both political and economic measures have strengthened transnational corporations, allowing a rap-

The Pandemic Health Crisis and FNS in Latin America id increase in the sale of ultraprocessed products and, consequently, in their production and consumption in the global south. This document reports that the annual per capita sale of ultraprocessed products increased in all Latin American countries between 2000 and 2013, with the fastest growth rates considered for the whole period being observed in Peru (107\%), Bolivia (129.8\%), and Uruguay (146.4\%). In the other countries, the growth in this period ranged from 8 to $59.8 \%$. These data have a direct impact on the general health conditions of the Latin American and Caribbean population, especially regarding their nutritional profile. There was a strong and significant association between the prevalence of obesity in adults and higher per capita sales of ultraprocessed products [39].

When bringing in the field of macropolitics - above all, economics - it is considered, therefore, a responsibility of nation states to conduct processes that promote FNS. Thus, the concepts of "food safety" and "food security" are reviewed [59].

In this pandemic scenario, it is possible to infer that the access and consumption of ultraprocessed products will tend to increase, given the reasons that hinder the purchase of fresh and in natura food, and the size of the hegemonic food system that values the segment of large industries, which, in turn, offers edible products at reduced costs. From the understanding of the different conceptions - of food safety and food security - it is possible to suppose that the population's FNS continues to be threatened since daily eating practices start to compose other senses of being/feeling. It is also relevant to mention that such threats and violations of the Human Right to Adequate Food (Direito Humano à Alimentação Adequadal DHAA in Portuguese) have been occurring over the last few years and that the current pandemic enhances the effects of these transformations on daily food.

For Paula [60]:

Hunger (malnutrition, overweight, and obesity) is directly associated with the deepening of social inequalities and the increase in poverty. (...) the processes of distribution of income and wealth are at the root of food problems, both in terms of limited access and the greater interest in ultraprocessed products, whose attractions, highlighted by advertising strategies, are the low prices, the ease of consumption, their appearance, and the imponderable appeal of modernity. The nutritional effects are neglected or camouflaged, contributing to the distancing of food from its natural condition and its importance to human beings (our translation).

A technical study mapping the food deserts in Brazil [30] demonstrates that the access of populations (vulnerable or not) to places that predominantly market edible 
(ultraprocessed) products is increasingly present. For the complexity of FNS, the dimension of physical access to food is a decisive and/or determining factor in achieving healthy eating practices $[61,62]$. Food choices are directly related to the food environment; it can provide opportunities for healthy behaviors, with fresh food and the diversity that the body needs, or, conversely, it can be an environment forged with edible products that are camouflaged as food [37].

The scenario of social inequalities and its implications for the geographic distribution of inadequate dietary patterns has intensified in the pandemic. In the urban network, especially in large centers and capitals, the lower availability of healthy foods, such as fruits and vegetables, to lower class families is associated with small neighborhood markets that work with higher prices and exhibit less variety and quality of fruits and vegetables $[63,64]$. It should be noted that in this composition of the community food microenvironment in areas of a lower purchasing power, there are still establishments such as "convenience stores" located in pharmacies and gas stations, for example, which guarantee access to ultraprocessed products, not because they are considered items of first necessity but because these products are strategically allocated in these commercial spaces that are considered essential [39]. Data from the Pan American Health Organization [39] indicate that most of these food products:

are designed and packaged for immediate consumption and (...) are offered in all types of retail establishments for food products, as well as in various nonfood outlets, many of which are open 24 h. Usually, they can be consumed anywhere. (...) are convenient, easy to store and transport and generally do not require crockery or cutlery, and (...) take the place of freshly cooked food (our translation).

\section{The Diet of Isolation and its Repercussions on Food Culture}

Food and nutritional security is directly linked to food culture. This happens through beliefs, representations, and practices that are intergenerationally retransmitted [65] and that are inserted "in a set of social processes for the production of food, the ecological nexus and uses of spaces, as well as their symbolic inferences linked to the modes and means of food consumption" [66].

Food is a cultural process and human beings symbolically mark the material and ecological basis of the space in which they live $[67,68]$. In capitalist societies, activities with a nutritional purpose involve complex mechanisms of production chains, employing specific rationality in the use of ecosystems, techniques, and science [37, 38]. All Amerindian societies - and here we consider isolated societies in tropical and subtropical forests, those in the process of continuous and regular exchanges with nonindigenous societies, and even the popular cultures of Latin American countries constituted by the hybridizations and fluid mosaics between tradition and modernity have cosmologies distinct from the rationality of Western tradition to some degree and to a certain extent $[69,70]$.

Multiculturalism, characteristic of the social formations that preceded the nation states in Latin America, gives particularities to territories, populations, habits, and cultural and food practices. They are ways of living that still represent an epistemological resilience to the expansion of the world system in the region $[52,70,71]$.

The restriction of circulation with the requirement to prepare food inside the home imposes food planning with items that have a longer shelf life. These are basically constituted by options with some degree of industrial processing and that meet hygiene and quality standards developed for industrial scale programming of the development of food products. In the diet of isolation, among the probable changes in food consumption models, there may be an increase not only in ultraprocessed but also in minimally processed foods (such as frozen food when the storing equipment is available), mainly because, as previously demonstrated, social distancing measures changed the dynamics of circulation and local trade of fresh products.

These transformations become more impactful when we consider the formation of long-term eating habits, with changes in preferences, taste, and culinary practices that incorporate a new way of reading and acting in the world produced during the pandemic. The domestic kitchen is transformed by the incorporation of industrialized products. Thus, the dimensions of the transformations in the food experience will require future research that considers, in a broader way, Latin American food models with their particular taxonomic classifications and set of rules regarding preparation, combination, and consumption $[37,66]$.

\section{Conclusions}

The question is how the food system survives and is strengthened with the decreasing availability of fresh and real food given the closure of street markets, popular restaurants, and the various types of street food trade in the 
global south, and especially in LAC. Certainly, the private sector's initiatives are extremely agile to maintain the circulation of ultraprocessed products in comparison to the fresh food trade conducted through street markets and short circuits of commercialization that demand the structuring of public policies.

In the face of pandemic urgency, which will probably accelerate food insecurity and increase hunger in countries with peripheral economies, while also increasing levels of obesity related to food deserts $[1,62,72-76]$, it is essential that food systems be rearranged so that they no longer provide edible products and start providing highquality diets.

Finally, it should be noted that, contrary to the neoliberal measures underway in Latin America, citing as an example the dismantling of the Brazilian state, in the face of the food insecurity crisis that is intensifying with the pandemic, there is an urgent need for the resumption of public policies, especially those of an emergency nature. Actions and programs that support family and agroecological agriculture, which strengthen institutional markets and public food security are experiences that have promoted advances in the Brazilian fight against hunger and can be resumed in the country and replicated in other regions. Reorganization of the dynamics of sales and access to family farming products, like street markets, and other initiatives of shorter marketing channels, such as kitchen (or potager) gardens and the case of urban consumption groups that bring producers and consumers together, should constitute the agendas of local managers. Public food security policies need to be expanded to combat unequal access to healthy food. This is because inequalities are the basis of the social determinants of the nutritional profile of the Latin American population in which hunger and malnutrition coexist with obesity.

\section{Conflict of Interest Statement}

The authors have no conflict of interests to declare.

\section{Funding Sources}

There has not been any kind of sponsorship or funding for our research.

\section{Author Contributions}

Rubia Carla Formighieri Giordani is responsible for the conception, writing, and final revision of the text. Islândia Bezerra da Costa is responsible for the conception and writing.

\section{References}

1 Food Security Information Network (FSIN). 2020 global report on food crisis: joint analysis for better decisions [Internet]. Rome: FSIN; 2020. [cited 2020 Apr 12]. Available from: https://docs.wfp.org/api/documents/ W F P - $0000114546 /$ d ownload / ? . $\mathrm{ga}=2.267372749 .210065150 .1587380654$ 754817525.1586777487

2 Organization for Economic Cooperation and Development. COVID-19 and global food systems [Internet]. Paris: OECD; 2020 [cited 2020 Apr 12]. Available from: https://read. oecd-ilibrary.org/view/?ref=134_134299 gywwih2rh3\&title=COVID-19-and-GlobalFood-Systems.

3 Organización de las Naciones Unidas para la Agricultura y la Alimentación; Organización Panamericana de la Salud; Programa Mundial de Alimentos (WFP); Fondo de las Naciones Unidas para la Infancia. Panorama de la seguridad alimentaria y nutricional en América Latina y el Caribe [Internet]. Santiago: FAO; 2019 [cited 2020 Apr 12]. Available from: www.fao.org/3/ca6979es/ca6979es.pdf.

4 Food Agriculture Organization. Climate change and food systems: global assessments and implications for food security and trade.
Rome: FAO; 2015 [cited 202o Apr 12]. Available from: http://www.fao.org/3/a-i4332e. pdf.

5 Comisión Económica para América Latina y el Caribe; Organización de las Naciones Unidas para la Alimentación y la Agricultura; Asociación Latinoamericana de Integración. Seguridad alimentaria, nutrición y erradicación del hambre CELAC 2025 Elementos para el debate y la cooperación regionales [Internet]. Santiago: CEPAL; 2016 [cited 2020 Apr 12]. Available from: http://www.fao. org/3/b-i6002s.pdf.

6 Gralak S, Spajic L, Blom I, Omrani OE, Bredhauer J, Uakkas S, et al. COVID-19 and the future of food systems at the UNFCCC. Lancet Planet Health. 2020 Aug;4(8):e30911.

7 Laurell AC. The mexican popular health insurance: myths and realities. Int $J$ Health Serv. 2015;45(1):105-25.

8 Laurell AC. Social policy and health policy in Latin America: a field of political struggle. Cad Saude Publica. 2017:33(suppl 2).

9 Breilh J. Epidemiologia crítica:ciência emancipadora e interculturalidade. Rio de Janeiro: FIOCRUZ; 2015.
10 Organisation for Economic Co-operation and Development; Economic Commission for Latin America and the Caribbean; Development Bank of Latin America. Latin American economic outlook 2017: youth, skills and entrepreneurship [Internet]. Paris: OECD; 2016. Available from: https://www.oecd.org/ dev/americas/E-Book_LEO2017.pdf.

11 d'Avila VAL, Fonseca AMM, Silva HP. Proteção social na América Latina e Caribe: mudanças, contradições e limites. Cad Saude Publica. 2017:33.

12 Naciones Unidas. Comisión Económica para América Latina y el Caribe. Social panorama of Latin America 2015. Santiago: CEPAL; 2016.

13 Organización Internacional del Trabajo. Panorana laboral 2019 América Latina y Caribe [Internet]. Lima: OIT; 2019 [cited 2020-0412]. Available from: https://www.ilo.org/wcmsp5/groups/public/--americas/--rolimhttps://www.ilo.org/wcmsp5/groups/ public/--americasa/documents/publication/ wcms_732198.pdf.

14 Wilkinson RG, Pickett KE. Income inequality and population health: a review and explanation of the evidence. Soc Sci Med. 2006 Apr; 62(7):1768-84.
The Pandemic Health Crisis and FNS in Latin America
Port J Public Health 2020;38:166-175 DOI: $10.1159 / 000512958$ 
15 Cecchini S, Filgueira F, Robles C. Social protection systems in Latin America and the Caribbean: a comparative view. Santiago: Comisión Económica para América Latina y el Caribe; 2014.

16 Cecchini S, Filgueira F, Martínez R, Rossel C. Instrumentos de protección social: caminos latinoamericanos hacia la universalización [Internet]Santiago: Comisión Económica para América Latina y el Caribe; 2015. [ [cited 2020 Apr 12]], Available from https://repositorio.cepal.org/bitstream/handle/11362/38821/S1500279_es.pdf;jsessionid $=$ D85969F0722F5F37CC6A414E0FC59C02? sequence $=1$

17 Giovanella L, Mendoza-Ruiz A, Pilar AC, Rosa MC, Martins GB, Santos IS, et al. Sistema universal de saúde e cobertura universal: desvendando pressupostos e estratégias. Cien Saude Colet. 2018 Jun;23(6):1763-76.

18 Funcia FR. Subfinanciamento e orçamento federal do SUS: referências preliminares para a alocação adicional de recursos. Cien Saude Colet. 2019 Dec;24(12):4405-15.

19 Londonõ J, Frenk J. Pluralismo estructurado. Washington (DC): BID Banco Interamericano de Desarrollo; 1997.

20 World Health Organization. Financiamento dos sistemas de saúde: o caminho para a cobertura universal: Relatório Mundial da Saúde 2010 [Internet]. Geneva: WHO; 2010 [cited 2020-04-12]. Available from: https://www. who.int/whr/2010/whr10_pt.pdf.

21 Organização Mundial da Saúde. Argumentando sobre la cobertura sanitaria universal. Geneva: WHO; 2013

22 World Health Organization. World Bank. Tracking universal health coverage: 2017 global monitoring report. New York (NY) WHO. World Bank; 2017.

23 Cárdenas WI, Pereira AM, Machado CV. Trajetória das relações público-privadas no sistema de saúde da Colômbia de 1991 a 2015. Cad Saude Publica. 2017 Jul;33(33 Suppl 2):e00114016.

24 Homedes N, Ugalde A. Twenty-five years of convoluted health reforms in Mexico. PLoS Med. 2009 Aug;6(8):e1000124.

25 Uribe-Gómez M. Nuevos cambios, viejos esquemas: las políticas de salud en México y Colombia en los años 2000. Cad Saude Publica. 2017 Jul;33(33 Suppl 2):e00112616.

26 Abel T, Frohlich KL. Capitals and capabilities: linking structure and agency to reduce health inequalities. Soc Sci Med. 2012 Jan;74(2):23644.

27 Lei No. 11.346 de 15 de setembro de 2006 D.O.U. de 18/09/2006, p. 1. Cria o Sistema Nacional de Segurança Alimentar e Nutricional - SISAN no Brasil com vista a assegurar o direito humano à alimentação adequada e a outras providências. Brasilia: Presidência da República; 2006.

28 United Nations. Sustainable development goals (SDGs). [Internet]. New York: United Nations Development Programme; 2020 [cited 2020-04-12]. Available from: https://www. undp.org/content/undp/en/home/sustain able-development-goals.html.

29 Heck M, Pilcher J, Ray K, Brito E. When eating becomes business. Rev Adm Empres. 2018;58(3):217-22.

30 Câmara Interministerial de Segurança Alimentar e Nutricional. Estudo técnico: mapeamento dos desertos alimentares no Brasil. Brasília: CAISAN; 2019.

31 Cardoso RC, dos Santos SM, Silva EO. Comida de rua e intervenção: estratégias e propostas para o mundo em desenvolvimento. Cien Saude Colet. 2009 Jul-Aug;14(4):1215-24.

32 Bezerra IN, Moreira TM, Cavalcante JB, Souza AM, Sichieri R. Food consumed outside the home in Brazil according to places of purchase. Rev Saude Publica. 2017 Mar;51(0):15.

33 Stewart H, Blisard N, Bhuyan S, Nayga R. The demand for food away from home: full-service or fast food? New York (NY): Economic Research Service. United States Department of Agriculture; 2004.[ [cited 2020 Apr 12]], Available from http://www.ers.usda.gov

34 Santos MV, Proença RP, Fiates GM, Calvo MC. Os restaurantes por peso no contexto de alimentação saudável fora de casa. Rev Nutr. 2011;24(4):641-9.

35 Padrão SM, Aguiar OB. Restaurante popular: a política social em questão. Physis Rev Saúde Coletiva. 2018;28(3):e280319.

36 Giordani RC, Bezerra I, Anjos MC. Semeando agroecologia e colhendo nutrição: rumo ao bem e bom comer. A política nacional de agroecologia e produção orgânica no Brasil: uma trajetória de luta pelo desenvolvimento rural sustentável. Brasília: IPEA; 2017.p. 43354.

37 Formighieri RC, Bezerra IB, de Carvalho SM. Escritos sobre o cuscuz. Rev Inter-Legere. 2019;2(25):1-27.

38 World Health Organization. Essential safety requirements for street-vended foods [Internet]. Geneva: WHO; 1996.

39 Organização Pan Americana de Saúde. Alimentos e bebidas ultraprocessados na América Latina: tendências, efeito na obesidade e implicações para políticas públicas. Brasília: OPAS; 2018

40 Bezerra IN, de Moura Souza A, Pereira RA, Sichieri R. Contribution of foods consumed away from home to energy intake in Brazilian urban areas: the 2008-9 Nationwide Dietary Survey. Br J Nutr. 2013 Apr;109(7):1276-83.

41 Boggs DA, Rosenberg L, Coogan PF, Makambi KH, Adams-Campbell LL, Palmer JR. Restaurant foods, sugar-sweetened soft drinks, and obesity risk among young African American women. Ethn Dis. 2013;23(4):445-51.

42 Buscemi S, Barile A, Maniaci V, Batsis JA, Mattina A, Verga S. Characterization of street food consumption in Palermo: possible ef fects on health. Nutr J. 2011 Oct;10(1):119.

43 Lachat C, Nago E, Verstraeten R, Roberfroid D, Van Camp J, Kolsteren P. Eating out of home and its association with dietary intake: a systematic review of the evidence. Obes Rev. 2012 Apr;13(4):329-46.
44 Food and Agriculture Organization. News \& highlights: Street foods around the world [Internet]. Rome: FAO; 2001 [cited $2020 \mathrm{Apr}$ 12]. Available from: http://www.fao.org/ News/2001/010804-e.htm.

45 Instituto Brasileiro de Geografia e Estatística. Pesquisa de orçamentos familiares 20172018: análise do consumo alimentar pessoal no Brasil. Rio de Janeiro: IBGE; 2019.

46 Freyre G. Casa-Grande e Senzala: formação da família brasileira sob o regime de economia patriarcal. Rio de Janeiro: José Olympio; 1933.

47 Tinker I. Legalizing street foods in the third world: the right to eat on the street. Whole Earth Rev. 1989:72-4.

48 Tinker I. Street foods into the 21st century. Agric Human Values. 1999;16(3):327-33.

49 Instituto Brasileiro de Geografia e Estatística. Censo Agropecuário 2017. Rio de Janeiro: IBGE; 2017.

50 Popkin BM. The nutrition transition: an overview of world patterns of change. Nutr Rev. 2004 Jul;62(7 Pt 2):S140-3.

51 Popkin BM, Adair LS, Ng SW. Global nutrition transition and the pandemic of obesity in developing countries. Nutr Rev. 2012 Jan; 70(1):3-21.

52 Mignolo W. Globalization, civilization processes and the relocation. In: Jameson F, Miyoshi M, editors. The cultures of globalization. London: Duke University Press; 1998. pp. 32-53.

53 Hernández JC. Patrimônio e globalização. In Canesqui AM, Garcia RW, editors. Antropologia e nutrição: um diálogo possível. Rio de Janeiro: Editora FIOCRUZ; 2005.

54 Friedmann H. Political economy of food: a global crisis. Oxford: New Left Review; 1993.

55 McMichael P, Friedman H. Agriculture and the state system: the rise and decline of national agriculture -1870 to the present. Sociol Ruralis. 1989;29(2):93-117.

56 Paula N, Delgado N. Fragmentation of Brazilian food system: between global markets and food security. J Food Secur. 2016;4(5):120-5.

57 Carrasco S. Antropologia i alimentació: una proposta per a l'estudi de la cultura alimentaria. Bellaterra: Servei de Publicacions UAB; 1992.

58 Monteiro CA, Levy RB, Claro RM, de Castro IR, Cannon G. Increasing consumption of ultra-processed foods and likely impact on human health: evidence from Brazil. Public Health Nutr. 2011 Jan;14(1):5-13.

59 King T, Cole M, Farber JM, Eisenbrand G, Zabaras D, Fox EM, et al. Food safety for food security: relationship between global megatrends and developments in food safety. Trends Food Sci Technol. 2017;68:160-75.

60 Paula NM. Prefácio. In: Perez-Cassarino J, Triches RM, Baccarin JG, Teo CR, editors. Abastecimento alimentar e mercados institucionais. Chapecó: UFFS; 2018.

61 Cohen DA, Hunter G, Williamson S, Dubowitz T. Are food deserts also play deserts? J Urban Health. 2016 Apr;93(2):235-43. 
62 Miller WC, Rogalla D, Spencer D, Zia N, Griffith BN, Heinsberg HB. Community adaptations to an impending food desert in rural Appalachia, USA. Rural Remote Health. 2016 Oct-Dec;16(4):3901.

63 Duran AC. Ambiente alimentar urbano em São Paulo, Brasil: avaliação, desigualdades e associação com consumo alimentar [Tese de doutoramento em Ciências]. São Paulo: Universidade de São Paulo; 2013.

64 Kasinski D. Desertos alimentares no município de São Paulo. São Paulo: Fundação Getúlio Vargas; 2020.

65 Hernández JC, Arnáiz MG. Alimentatión y cultura: perspectivas antropológicas. Barcelona: Ariel; 2005.
66 Giordani RC, Fidelis L, Bergamasco S. Comunidades tradicionales brasileñas y seguridad alimentaria y nutricional: articulaciones necesarias entre cultura y territorio. Espac Reg Rev Estud Soc. 2016;1:13-22.

67 Condominas G. L'espace social a propos de l' Asie du Sud-Est. Paris: Flammarion; 1980.

68 Hubert A. L'alimentation dans un village Yao de Thailande du Nord: de l'au delà au cuisine. Paris: CNRS; 1985

69 Canclini NG. Culturas híbridas. São Paulo: EdUSP; 2008.

70 Santos BS, Meneses MP. Epistemologias do sul. Coimbra: Almedina; 2009.

71 Wallerstein I. Unthinking social science: the limits of nineteenth-century paradigms. Cambridge: Polity; 1991.

72 Ghosh-Dastidar B, Cohen D, Hunter G, Zenk SN, Huang C, Beckman R, et al. Distance to store, food prices, and obesity in urban food deserts. Am J Prev Med. 2014 Nov;47(5):58795.
73 Ghosh-Dastidar M, Hunter G, Collins RL, Zenk SN, Cummins S, Beckman R, et al. Does opening a supermarket in a food desert change the food environment? Health Place. 2017 Jul;46:249-56.

74 Ramirez AS, Diaz Rios LK, Valdez Z, Estrada E, Ruiz A. Bringing produce to the people: implementing a social marketing food access intervention in rural food deserts. J Nutr Educ Behav. 2017 Feb;49(2):166-174.e1.

75 Lytle LA, Sokol RL. Measures of the food environment: A systematic review of the field, 2007-2015. Health Place. 2017 Mar;44:18-34.

76 Sushil Z, Vandevijvere S, Exeter DJ, Swinburn B. Food swamps by area socioeconomic deprivation in New Zealand: a national study. Int J Public Health. 2017 Nov;62(8):869-77. 